\title{
LIFE SATISFACTION AND POSITIVITY LEVELS OF MUS WORKERS OF PROVINCIAL DIRECTORATE OF YOUTH AND SPORTS
}

\author{
Mustafa Önder ȘEKEROĞLU ${ }^{1}$ \\ ${ }^{1}$ Muş Alparslan Üniversitesi Beden Eğitimi ve Spor Yüksekokulu, MUŞ
}

\begin{abstract}
The purpose of this study is to determine the life satisfaction and positivity levels of the personnel working in different units of the Mus Youth and Sports Provincial Directorate. In this study conducted on 87 staff; The levels of life satisfaction and positivity of the personnel were determined, and the levels of life satisfaction and positivity were examined in terms of socio-economic, demographic and descriptive characteristics. In this research, a general scanning model, which is one of the descriptive research methods, is applied. In the study, with the personal information form developed by the researchers, Life Satisfaction Scale developed by Diener, Emmons, Laresen and Griffin (1985) and Positivity Scale developed by Caprara, Alessandri, Eisenberg, Kupfer, Steca, Caprara and Abela (2012) were used. In the analysis of data, T-test and multiple comparisons anova test were used for two independent groups. Whether the data provides the assumption of normality is measured by the skewness and kurtosis test. The data collected from the participants within the scope of positivity level research; mann whitney u test and multiple comparisons for two independent groups were analyzed using Kruskal Wallis. As the result of the analysis did not provide the normality assumption, it was decided that it was suitable for the application of nonparametric tests.In this study, life satisfaction and positivity levels of the participants were affected by income levels; It was found that age, gender, marital status and educational status did not cause statistically significant difference in life satisfaction and positivity level.
\end{abstract}

Key Words: Life Satisfaction, Positivity, Youth and Sports

Öz: Bu çalışmanın amacı, Muş Gençlik ve Spor İl Müdürlüğünün farklı birimlerinde görev yapan personelin yaşam doyumu ve pozitiflik düzeylerini belirlemektir. 87 personel üzerinde yürütülen bu çalışmada; personelin yaşam doyumu ve pozitiflik düzeyleri belirlenmiş, yaşam doyumu ve pozitiflik düzeyleri sosyo-ekonomik, demografik ve tanımlayıcı özellikleri açısından incelenmiştir. Bu araştırmada betimsel araştırma yöntemlerinden biri olan, genel tarama modeli uygulanmıştır. Çalışmada, araştırmacılar tarafından geliştirilen kişisel bilgi formu ile Diener, Emmons, Laresen and Griffin (1985) tarafindan geliştirilen Yaşam Doyum Ölçeği ile Caprara, Alessandri, Eisenberg, Kupfer, Steca, Caprara and Abela (2012) tarafindan geliştirilen Pozitiflik Ölçeği kullanılmıştır. Verilerin analizinde, bağımsız iki grup için T-testi ve çoklu karşılaştırmalar anova testi kullanılmıştır. Verilerin normallik varsayımını sağlayıp sağlamadığı çarpıklık ve basıklık testi ile ölçülmüştür. Pozitiflik düzeyi araştırması kapsamında katılımcılardan toplanan veriler; bağımsız iki grup için mann whitney u testi ve çoklu karşılaştırmalar Kruskal Wallis kullanılarak analiz edilmiştir. Analiz sonucu çıkan değerlerin normallik varsayımını sağlamadığı için nanparametrik testlerin uygulanmasına uygun olduğuna karar verilmiştir. $\mathrm{Bu}$ çalışmada katılımcıların yaşam doyum ve pozitiflik düzeylerinin gelir düzeylerinden etkilendiği; yaş, cinsiyet, medeni durum ve öğrenim durumlarının yaşam doyum ve pozitiflik düzeyi üzerinde istatistiksel olarak farklılığa neden olmadığı saptanmıştır.

Anahtar Kelimeler: Yaşam Doyumu, Pozitiflik, Gençlik ve Spor

\section{INTRODUCTION}

The effects of rapidly developing communication and technology are seen in every field today. Especially the socio-economic and cultural values that have changed together with the social problems and negativities of the individuals have changed their life perspective and 
unhappiness has emerged throughout the society. (Başoğlu, Şekeroğlu ve Altun, 2016a). Maintaining a happy life is undoubtedly one of the leading life goals for many people. It is known that happiness, which is tried to be understood and obtained through questions such as how happy one can be, what happiness means and what factors are affected, is an important subject for people (Çivitçi, 2012). Happiness is one of the conditions required for life satisfaction One of the best ways for people to evaluate their living conditions and happiness levels is to learn the levels of life satisfaction and positivity.

In order to define the concept of life satisfaction, first of all, the concept of satisfaction must be explained. Satisfaction is the satisfaction of meeting expectations, needs, desires and desires. The concept of satisfaction; it is the inner peace and pleasure that one cannot directly observe (Şad, 2017 Life satisfaction, the quality of life, the degree of being positive is a set of processes related to people's life patterns and standards. Life satisfaction is a cognitive assessment of how a person looks at his / her life and how good his or her life is. The variables such as income status, occupational status, place of work, environmental conditions and expectation levels of individuals are the factors affecting their life satisfaction. Therefore, the way employees feel job satisfaction and occupational burnout levels affect their life satisfaction (Avşaroğlu, Deniz and Kahraman, 2005; Şimşek and Aktaş, 2014).

It is seen that the science of psychology investigating the nature and behaviors of the individual has adopted an approach towards the improvement of the people for a long time, especially because of the negativity in the Second World War. However, this pathologyoriented attitude has ignored the happiness and developmental characteristics of people, and in order to overcome this deficiency, a positive psychology movement has emerged which aims to develop positive characteristics of people and brings a balanced and coherent approach to human behavior (Seligman and Csikszentmihalyi, 2000).

Positivity is a positive attitude towards the person, past and future experiences, or evaluating them positively. People who have a positive approach to events try to stay away from stress and have a comfortable and peaceful life. Persons with negative approach to events are in a stressful, aggressive and dissatisfied structure. Studies show that there is a significant relationship between positive thinking and feeling and life satisfaction (Özdevecioğlu, 2003; Froh, Yurkewicz and Kashdan, 2009; Caprara et al., 2010).

One of the factors that affect life satisfaction and positive thinking is working life which has a very important place in one's life. Self-esteem, life satisfaction and optimism are highly related among themselves; Health, business success and positive interpersonal relationships are related to many factors (Çıkrıkçı, Çiftçi ve Gençdoğan, 2015). In order for life satisfaction to be positive, work and life balance should be established. The individual, who is considered important in his work, meets the job satisfaction, and this is reflected in the work of the individual as a positive factor (Morgenstern, 2004; Keser, 2005).

Organizational and individual productivity should be increased, and life satisfaction and positive thinking should be kept at a high level to ensure productivity. It can be said that individuals who work in sport organizations work under pressure due to many different reasons in their working environment and daily life and they are experiencing physical, psychological and social transitions due to this pressure. In this respect, considering the Provincial Directorate of Youth and Sports that manages and directs the sport in the provinces, life satisfaction and positivity levels of the employees working in the sports institutions are of great importance in achieving the determined goals and targets. In this context, it was aimed to investigate the life satisfaction and positivity levels of the individuals working in different units of Mus Youth and Sports Provincial Directorate. 


\section{METHOD}

\section{Research Model}

In this research, a general scanning model, which is one of the descriptive research methods, was applied. Information about the subject has been obtained from the screening of resources and the application of the data collection tool. In relational screening models, which is one of the types of scanning model; the presence and / or degree of interchange between two or more variables is determined. Relational screening is done in two ways: correlation type relationship and relationship obtained by comparison (Karasar, 1999; İslamoğlu, 2003).

\section{Universe and Sample}

The universe of the study consists of 133 staff working in different positions in different departments of Muş Youth and Sports. The sample group consists of 87 employees who agreed to participate voluntarily.

\section{Data Collection Tools}

In this study as a data collection tool, "Personal Information Form" developed by researchers and "Positivity Scale" developed by Caprara et al. (2012) in order to evaluate the positivity levels of individuals directly and "Life Satisfaction Scale" developed by Diener, Emmons, Larsen and Griffin (1985) in order to measure the overall life satisfation of individuals.

\section{The Satisfaction with Life Scale}

"The Satisfaction with Life Scale (SWLS) was developed by Diener, Emmons, Larsen and Griffin (1985) to measure the overall life satisfaction of individuals. The Life Satisfaction Scale is a 5-item, single-factor, and Likert-type self-assessment scale. The scale is answered by marking the degrees between exactly inappropriate (1) and completely appropriate (7). Low scores from the scale (minimum 5) indicate low life satisfaction and high scores (highest 35) indicate high life satisfaction. Turkish adaptation of the scale was performed by Köker (1991) .

The Cronbach Alpha internal consistency coefficient of the scale was calculated as 0,870 in this study. Depending on the alpha coefficient, the reliability of the scale is interpreted as: $0.00 \leq$ alpha $\leq 0.40$ if the scale is not reliable, $0,40 \leq$ alpha $\leq 0,60$ the reliability of the scale is low, $0,60 \leq$ alpha $\leq 0,80$ the scale is quite reliable. $0,80 \leq$ alpha $\leq 1,00$ the scale is highly reliable (Kalayc1, 2008). According to this result $(0,829)$, it can be said that the result of the study is quite reliable.

\section{Positivity Scale}

Positivity Scale was developed by Caprara et al. (2012) in order to evaluate the positivity levels of individuals directly. The original form of the measurement tool has a five-point Likert-type assessment. The Positivity Scale consists of four sub-dimensions that measure eight items and individuals themselves, their expectations from the future, their perceptions of trust towards other people and their perception of satisfaction from life. The validity and reliability study of the Positivity Scale adapted to the Turkish population was conducted by Çıkrıkçı, Çiftçi and Gençdoğan (2015). 
The Cronbach Alpha internal consistency coefficient of the scale was calculated as " $0,829 "$. The reliability of the scale is interpreted according to the alpha coefficient: $0,00 \leq$ alpha $\leq 0,40$ the scale is not reliable, $0,40 \leq$ alpha $\leq 0,60$ the reliability of the scale is low, $0,60 \leq$ alpha $\leq 0,80$ the scale is highly reliable, $0,80 \leq$ alpha $\leq 1$, the scale is highly reliable (Kalayc1, 2008).

According to this result $(0,829)$, it can be said that the result of the study is quite reliable.

\section{Data Analysis}

First of all arithmetic mean, standard deviation, frequency / percentage, normal distribution test (skewness and kurtosis coefficients) were investigated. Than the skewness and kurtosis values of the variables are checked $( \pm 1)$ as the assumption of normality (Büyüköztürk, 2010). The data in this study show that the skewness and kurtosis values of the variables are above the recommended criterion value (Table 1). Therefore, t-test (Mann-Withney U test) was used for pairwise comparisons, and variance analysis (Kruskal Wallis-H test) was used for multiple comparisons. After the variance analysis test, in order to determine the significant difference between the income level variables, the paired comparisons were made and the bonferroni correction method was used to prevent the type I and type II errors that could result from these binary comparisons [level of significance (0.05) Mann-Whitney $U$ test was divided into (10) and significance level was determined as (0.005)].

\section{RESULTS}

Table 1. Socio-economic, demographic and descriptive statistics for participants

\begin{tabular}{|c|c|c|c|c|c|c|c|}
\hline \multirow{2}{*}{$\begin{array}{l}\text { Demographic } \\
\text { Variables }\end{array}$} & & \multirow{2}{*}{$\mathbf{N}$} & \multirow{2}{*}{$\%$} & \multicolumn{2}{|c|}{ Life satisfaction } & \multicolumn{2}{|c|}{ Pozitiveness } \\
\hline & & & & Skewness & Kurtosis & Skewness & Kurtosis \\
\hline \multirow[b]{2}{*}{ Gender } & Female & 13 & 14,9 & -604 & -740 & -1.238 & 1.439 \\
\hline & Male & 74 & 85,1 & -1.238 & -1.403 & -1.900 & 2.974 \\
\hline \multirow{5}{*}{ Age } & 20-24 years & 8 & 9,2 & -.809 & 1.316 & -1.890 & 4.368 \\
\hline & 25-29 years & 16 & 18,4 & -.271 & -1.575 & -1.260 & 1.604 \\
\hline & $30-34$ years & 29 & 33,3 & -.944 & -.112 & -2.213 & 5.076 \\
\hline & 35- 39 years & 12 & 13,8 & -1.230 & .521 & -.896 & .178 \\
\hline & $\begin{array}{l}40 \text { years and } \\
\text { over }\end{array}$ & 22 & 25,3 & -.219 & -.982 & -.803 & -.139 \\
\hline \multirow{6}{*}{$\begin{array}{l}\text { Education } \\
\text { status }\end{array}$} & Primary school & 3 & 3,4 & 1.090 & .000 & 1.732 & .000 \\
\hline & $\begin{array}{l}\text { Secondary } \\
\text { School }\end{array}$ & 5 & 5,7 & .592 & -.809 & -.523 & -3.148 \\
\hline & High school & 24 & 27,6 & -.765 & -.277 & -.934 & 1.729 \\
\hline & Associate Degree & 11 & 12,6 & -.632 & -1.245 & -1.536 & 1.751 \\
\hline & License & 40 & 46,0 & -.938 & -.169 & -1.891 & 3.119 \\
\hline & Master's Degree & 4 & 4,6 & -.475 & -3.321 & -2.000 & 4.000 \\
\hline \multirow{2}{*}{$\begin{array}{l}\text { Marital } \\
\text { status }\end{array}$} & Single & 22 & 25,3 & -.994 & -.147 & -1.420 & 1.718 \\
\hline & Married & 65 & 74,7 & -.599 & -.733 & -1.345 & 1.685 \\
\hline \multirow{5}{*}{ Income rate } & Lower & 16 & 18,4 & .817 & -.454 & .401 & -.930 \\
\hline & Lower - Medium & 43 & 49,4 & -1.047 & .340 & -1.318 & 1.504 \\
\hline & Middle & 20 & 23 & -.811 & .062 & -1.316 & 1.626 \\
\hline & Medium - Top & 5 & 5,7 & 1.573 & 3.378 & .437 & -2.681 \\
\hline & Upper & 3 & 3,4 & -1.732 & .000 & -1.458 & .000 \\
\hline
\end{tabular}

$85.1 \%$ of the participants were male and $14.9 \%$ were female. $9.2 \%$ of the participants were 20-24 years old, $18.4 \%$ were $25-29$ years, $33.3 \%$ were $30-34$ years, $13.8 \%$ were $35-39$ years, $25.3 \%$. and 40 years of age and over. $3.4 \%$ of the participants were primary school graduates, 
$5.7 \%$ were secondary school graduates, $27.6 \%$ were high school graduates, $12.6 \%$ were associate degrees, $46 \%$ were undergraduate, $4.6 \%$ He also holds a master's degree. $25.3 \%$ of the participants were single and $74.7 \%$ of them were married. $18.4 \%$ of the participants were in the lower level, $49.4 \%$ in the lower-middle level, $23 \%$ in the middle level, $5.7 \%$ in the middle-upper level and $3.4 \%$ in the upper level group.

Table 2. Comparison of positive and life satisfaction levels of the participants according to gender variable

\begin{tabular}{llccccc}
\hline $\begin{array}{l}\text { Dependent } \\
\text { Variables }\end{array}$ & Gender & N & Mean Rank & Sum of Ranks & U & p \\
\hline \multirow{2}{*}{ Positiveness } & Female & 13. & 45.69 & 594,00 & 459.00 & .792 \\
\hline \multirow{2}{*}{ Life satisfaction } & Male & 74 & 43.70 & 3234,00 & 0 & \\
\hline Female & 13 & $\mathbf{4 9 . 8 5}$ & 2056.50 & 405.00 & .363 \\
& Male & 74 & 42.97 & 5693.50 & 0 &
\end{tabular}

According to the gender variable, t-test results for determining the significant difference between the positive and life satisfaction levels of the participants are presented in Table 2 . The Mann-Withney U test was used to test whether there was a significant difference in the positivity and life satisfaction levels of the participants. No statistically significant difference was found.

Table 3. Comparison of positive and life satisfaction levels of participants according to marital status variable

\begin{tabular}{|c|c|c|c|c|c|c|}
\hline $\begin{array}{l}\text { Dependent } \\
\text { Variables }\end{array}$ & Marital status & $\mathbf{N}$ & Mean Rank & Sum of Ranks & $\mathbf{U}$ & $\mathbf{p}$ \\
\hline \multirow{2}{*}{ Positiveness } & Single & 22 & 46.66 & 1026.50 & \multirow{2}{*}{656.500} & \multirow{2}{*}{.566} \\
\hline & Married & 65 & 43.10 & 2801.50 & & \\
\hline \multirow{2}{*}{ Life satisfaction } & Single & 22 & 43.05 & 947.00 & \multirow{2}{*}{694.000} & \multirow{2}{*}{.837} \\
\hline & Married & 65 & 44.32 & 2881.00 & & \\
\hline
\end{tabular}

According to the marital status variable of the participants, t-test results for determining the significant difference between positivity and life satisfaction levels are presented in Table 3 . As a result of the Mann-Whitney $U$ test, there was no statistically significant difference between the participants' positivity $(U=656.500, p>0.05)$ and life satisfaction $(U=694.000$, p> 0.05) and age variables.

Table 4. Variance analysis results of the participants' positivity and life satisfaction levels according to the educational status variable

\begin{tabular}{lllccccc}
\hline $\begin{array}{l}\text { Dependent } \\
\text { Variables }\end{array}$ & Education status & $\mathbf{N}$ & Mean Rank & df & $\boldsymbol{\chi 2}$ & $\mathbf{p}$ & (I-J) \\
\hline & 1.Primary school & 3 & 22.50 & & & & \\
Positiveness & 2.Secondary School & 5 & 39.00 & & & \\
& 3.High school & 24 & 39.08 & 5 & 8.708 & .121 \\
& 4.Associate Degree & 11 & 56.41 & & & \\
& 5.License & 40 & 47.53 & & & \\
\hline
\end{tabular}




\begin{tabular}{llllllll}
\hline & 6.Master's Degree & 4 & 26.50 & & & \\
\cline { 5 - 6 } & 1.Primary school & 3 & 31.67 & & & \\
& 2.Secondary School & 5 & 23.80 & & & \\
Life satisfaction & 3.High school & 24 & 42.25 & & & \\
& 4.Associate Degree & 11 & 56.67 & 5 & 9.312 & .097 \\
& 5.License & 40 & 46.94 & & & \\
\hline$* \mathrm{P}<0,05 ; \mathrm{N}(87)$ & 6.Master's Degree & 4 & 25.88 & & \\
\end{tabular}

The results of the variance analysis for determining the significant difference between the educational status variable and the positivity and life satisfaction levels are presented in Table 4. As a result of the Kruskal Wallis $\mathrm{H}$ test, the educational variable of the participants and the positivity variable $0.052(\mathrm{sd}=5, \mathrm{n}=87)=8.708, \mathrm{p}>0.05)$ and the life satisfaction variable $(\mathrm{sd}=5, \mathrm{n}=87)=9.312, \mathrm{p}>$ In 0.05$)$, no statistically significant difference was found.

Table 5. Variance analysis results of the participants' positivity and life satisfaction levels according to the income level variable

\begin{tabular}{|c|c|c|c|c|c|c|c|}
\hline $\begin{array}{l}\text { Dependent } \\
\text { Variables }\end{array}$ & Income rate & $\mathbf{N}$ & $\begin{array}{l}\text { Mean } \\
\text { Rank }\end{array}$ & df & $\chi^{2}$ & $\mathbf{p}$ & (I-J) \\
\hline \multirow{5}{*}{ Positiveness } & 1. Lower & 16 & 25.47 & \multirow{5}{*}{4} & \multirow{5}{*}{14.009} & \multirow{5}{*}{.007} & \multirow{5}{*}{$1-2,1-3$} \\
\hline & $\begin{array}{l}\text { 2.Lower- } \\
\text { intermediate }\end{array}$ & 43 & 45.88 & & & & \\
\hline & 3.Intermediate & 20 & 52.48 & & & & \\
\hline & 4.Mid-upper & 5 & 60.40 & & & & \\
\hline & 5.Top & 3 & 32.00 & & & & \\
\hline \multirow{5}{*}{ Life satisfaction } & 1.Lower & 16 & 23.97 & \multirow{5}{*}{4} & \multirow{5}{*}{14.577} & \multirow{5}{*}{.006} & \multirow{5}{*}{$1-2,1-3$} \\
\hline & $\begin{array}{l}\text { 2.Lower- } \\
\text { intermediate }\end{array}$ & 43 & 50.02 & & & & \\
\hline & 3.Intermediate & 20 & 49.00 & & & & \\
\hline & 4.Mid-upper & 5 & 45.60 & & & & \\
\hline & 5.Top & 3 & 28.50 & & & & \\
\hline
\end{tabular}

The results of variance analysis to determine the meaningful difference between the income level of the participants and the positivity and life satisfaction variables are presented in Table 5. As a result of the Kruskal Wallis $H$ test, the income level and positivity were $\mathrm{n} 2(\mathrm{sd}=4, \mathrm{n}$ $=87)=14.009, \mathrm{p}<0.05)$ and life satisfaction variables $\chi 2(\mathrm{sd}=4, \mathrm{n}=87)=14.577, \mathrm{p}<0.05)$ significant differences were found. Mann Whitney $U$ tests were applied to determine the income level category of the differences in positivity and life satisfaction variables of the participants. As a result of the tests, in the positivity variable, with lower income level and lower-middle income $(\mathrm{U}=179.500, \mathrm{p}<0.005)$ have middle income with participants and lower income level $(\mathrm{U}=63.500, \mathrm{p}<0.005)$ statistically significant difference was found between the participants. Similarly, in life satisfaction variable, it has lower-middle income with lower income level $(\mathrm{U}=153.500, \mathrm{p}<0.005)$ have middle income with participants and lower income level $(\mathrm{U}=65.500, \mathrm{p}<0.005)$ there was a statistically significant difference between participants.

Table 6. Variance analysis results according to age variable of positivity and life satisfaction levels of participants

\begin{tabular}{|c|c|c|c|c|c|c|c|}
\hline $\begin{array}{l}\text { Dependent } \\
\text { Variables }\end{array}$ & Age & $\mathbf{N}$ & Mean Rank & df & $\chi^{2}$ & $\mathbf{p}$ & (I-J) \\
\hline Positiveness & $\begin{array}{l}\text { 1. } 20-24 \text { years } \\
\text { 2. } 25-29 \text { years }\end{array}$ & $\begin{array}{c}8 \\
16\end{array}$ & $\begin{array}{l}56.14 \\
43.28\end{array}$ & 4 & 7.312 & .120 & \\
\hline
\end{tabular}




\begin{tabular}{|c|c|c|c|c|c|c|}
\hline \multirow[t]{3}{*}{ 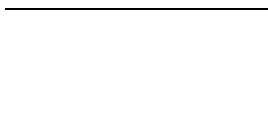 } & \multirow{2}{*}{$\begin{array}{l}\text { 3. } 30-34 \text { years } \\
\text { 4. } 35 \text { - } 39 \text { years }\end{array}$} & 29 & 48.43 & & & \\
\hline & & 12 & 46.42 & & & \\
\hline & 5. 40 years and over & 22 & 32.84 & & & \\
\hline \multirow{5}{*}{ Life satisfaction } & 1. $20-24$ years & 8 & 50.69 & \multirow{5}{*}{4} & \multirow{5}{*}{2.971} & \multirow{5}{*}{.563} \\
\hline & 2. $25-29$ years & 16 & 43.50 & & & \\
\hline & 3. $30-34$ years & 29 & 47.17 & & & \\
\hline & 4. $35-39$ years & 12 & 45.96 & & & \\
\hline & 5. 40 years and over & 22 & 28.50 & & & \\
\hline
\end{tabular}

Results of the variance analysis for determining the significant difference between the age variable of the participants and positivity and life satisfaction levels are presented in Table 6 . As a result of the Kruskal Wallis $\mathrm{H}$ test, the variables of age variable and positivity $\chi^{2}(\mathrm{sd}=4$, $\mathrm{n}=87)=7.312, \mathrm{p}>0.05)$ and life satisfaction variable $\left.\chi^{2}(\mathrm{sd}=4, \mathrm{n}=87)=2.971, \mathrm{p}>0.05\right)$ statistically significant difference was not found.

\section{DISCUSSION}

As a result, life satisfaction and positivity levels of Muş Youth and Sports Provincial Directorate employees were examined in terms of some socio-economic and demographic variables.

As a result of the findings, there was no statistically significant relationship between gender and life satisfaction level. In a study conducted by Basoglu, Şekeroğlu and Altun (2016b) with the Ankara Provincial Directorate of Youth and Sports, no significant relationship was found between gender and life satisfaction. In addition, Giusta, Jewell, and Kambhampati (2011), Bergan and McConahta (2001) stated that there is no significant relationship between gender and life satisfaction in their studies. The findings of these studies support study. When the literature is examined, it is seen that gender variable causes differentiation on life satisfaction level (Telef, 2011; Tiefenbach and Kohlbacher, 2013). As a matter of fact in his, study Koçak (2016) stated that female students' life satisfaction is significantly higher than male students.

No significant difference was found in the comparison of life satisfaction of the participants according to age groups. According to this result, there is not a significant difference between the life satisfactions of the age groups who are not much difference between them. In the Toker's study in order to determine the life satisfaction of academicians; life satisfaction of academics aged 51 years and older was higher than the life satisfaction of academicians between 31-40 and 41-50 years old. Unal, Karlıdağ and Yoloğlu (2001) in his study on physicians; The life satisfaction of those in the age group of 40 and over were higher than the age groups of 22-29 and 30-39. While these results were in contrast with our study, in the studys made by Avşaroğlu, Deniz and Kahraman (2005), Yiğit, Dilmaç and Deniz (2011), Kaplan (2014), they found no significant relationship between age and life satisfaction level. These results support our findings.

Significant difference was not found in the comparison of life satisfaction and positivity levels of the participants according to the educational status variable. The results obtained from the studies of Kocaçal (2016), Ekin (2018) and Aslan (2017) show that the education level has no effect on positive thinking and these results are in parallel with the findings of our study. However, the results of the study on the relationship between education and happiness are contradictory. People with undergraduate and graduate degrees are generally expected to have a higher income and social status and are therefore more happy (Koçak, 2016). Cheung and 
Chan (2009) in 45 countries in the research conducted in countries with high levels of life satisfaction is also found to be high. In another study by Gong, Cassells and Keeagan (2011), it was found that the relationship between education and life satisfaction was at different levels in different age groups. As a result of the studies conducted by Uygungil (2017), it was found that there was a significant relationship between education level and life satisfaction. These results are not similar to the findings of our study.

In our study, it was determined that life satisfaction and positivity level had significant difference compared to the income level variable. According to these findings, it can be concluded that as the level of income increases, the level of life satisfaction and the level of positivity increase. When the other studies related to the subject are examined, it is seen that there are studies in parallel with the results of our study (Y1lmaz and Altınok, 2009; Toker, 2012; Kabasakal and Baş, 2013; Kuzulu, Kurtuldu and Özkan 2013; Şekeroğlu, 2013). It is known that the strongest socio-structural predictor of goodness, positive thinking, and pleasure from life is the income and social status (Staudinger, Fleeson and Baltes, 1999). The economic and financial situation can be interpreted as a possible result because it can be a determinant of life satisfaction and positivity as it is determinative in many subjects such as meeting the basic needs of individuals, making future plans and living their social lives.

According to the age and gender, there is no significant differences in positivity level of the participants. This result is consistent with the results of the researches conducted by Polatç1 (2011), Kara (2014) and Uygungil (2017). This shows that the level of positivity is independent of these two variables, which do not vary by gender and age.

In our study, no significant difference was found between the life satisfaction and positivity levels and marital status of the participants. This result can be interpreted as that the life satisfaction and positivity levels of the participants who are married with single participants are similar. The findings of Aslan (2017), Şad (2017) and Ekin (2018) also support our study. Studies investigating the relationship between marital status and life satisfaction and positivity generally have a positive relationship between these two concepts. When the studies are examined, there is a positive relationship between life satisfaction and positivity and marital status (Koçak, 2016).

\section{CONCLUSION}

As a result, age, gender, marital status and educational status did not cause any difference on life satisfaction and positivity. However, income level was found to be an effective variable on life satisfaction and positivity. Considering that the individuals' happiness and happiness in life and their positive attitude towards events and situations are affected by psychological and physiological factors, studies on the subject can be done in this direction. Considering the fact that working environments have an important place in the lives of individuals, negativity in the workplace may cause unrest in the general life and affect the life satisfaction and positivity, managers taking measures in this sense, meeting social expectations in the working environment with cultural and sportive activities can increase the life satisfaction levels of the employees.

\section{REFERENCES}

Aslan, İ. (2017). Investigation of the relationship between teachers' positive psychological capital perceptions and their organizational commitment (Master Thesis). Siirt University Social Sciences Institute, Siirt. 
Avşaroğlu, S., Deniz, M. E. and Kahraman A. (2005). Life Satısfactıon In Technıcal Teachers Investıgatıon Of Professional Deployment Levels. Selçuk University Journal of Social Sciences Institute, 14, 115-129.

Başoğlu, B., Şekeroğlu, M.Ö. ve Altun, E. (2016a). Effects of Teachers on Work-Family Conflict, Family-Work Conflict and Life Satisfaction and Some Demographic Variables. The Journal of Academic Social Science, 4(32), 277-291.

Başoğlu, B., Şekeroğlu, M.Ö. ve Altun, E. (2016b). The Investigation of Work-Family Conflict, Family-Work Conflict and Life Satisfaction According to Different Variations. Ömer Halis Demir University Journal of Physical Education and Sport Sciences. 1(10), 153-163.

Bergan, A. and Mcconatha, J. T. (2001). 'Religiosity and Life Satisfaction, Activities', Adaptation and Aging, 24(3), 23-34.

Büyüköztürk, Ş. (2011). Manual of Data Analysis for Social Sciences: Statistics, Research Pattern SPSS Applications and Comments. Pegem A Publishing.

Caprara, G. V., Steca, P., Alessandri, G., Abela, J. R. Z. and McWhinnie, C. M. (2010). Positive Orientation: Explorations On What İs Common To Life Satisfaction, Self-Esteem, And Optimism. Epidemiologia e Psichiatria Sociale, 19, 63-71.

Caprara, G. V., Alessandri, G., Eisenberg, N., Kupfer, A., Steca, P., Caprara, M. G. and Abela, J. (2012). The Positivity Scale. Psychological Assessment, 24, 701-712.

Cheung, H. Y. and Chan, A. W. H. (2009). 'The Effect of Education on Life Satisfaction Across Countries. The Alberta Journal of Educational Research, 55, (1), 124-136.

Chubon, R. A. (1987). Development of a Quality-of-Life Rating Scale for Use in Health-care Evaluation. Evaluation and the Health Professions, 10, 186-200.

Çıkrıkçı, Ö., Çiftçi, M. ve Gençdoğan, B. (2015). Psychometric properties of Turkish version of Positivity Scale. The Journal of Happiness \&Well-Being, 3(1), 57-76.

Diener, E., Emmons, R. A., Laresen, R. J. and Griffin, S. (1985).The Satisfaction With Life Scale. Journal of Personality Assessment, 49, 71-75.

Ekin, A. (2018). Investigation of Positive Psychological Capital Perceptions of Physical Education and Sports Teachers in terms of Some Variables. Master Thesis, Karamanoğlu Mehmetbey University, Karaman.

Froh, J. J., Yurkewicz, C. and Kashdan, T. B. (2009). Gratitude And Subjective Well-Being In Early Adolescence: Examining Gender Differences, Journal of Adolescence 32(3), 633-650.

Giusta, D. M., Jewell, S. L. and Kambhampati, U. S. (2011). Gender and Life Satisfaction In The UK, Feminist Economics, 17(3), 1-34.

Gong, H., Cassells, R. and Keeagan, M. (2011). Understanding Life Satisfaction and the Education Puzzle in Australia, Çalnatsem Working Paper 11/12 HILDA Conference, July

Harriett, K. Light, Hertsgaard D. and Martin R. E. (1985). Education And Income: Significant Factors İn Life Satisfaction Of Farm Men and Women, Research in Rural Education, 3, 7-12.

Kabasakal, Z. ve Uz Baş, A. (2013). Problem Solving Skills as a Predictor of Life Satisfaction in Teacher Candidates, Journal of Educational Research, 1, 27-35.

Kaplan, H. (2014). Job Satisfaction - Relation of Life Satisfaction (Denizli Servergazi State Hospital Nurse Midwife Nurses Example). Master Thesis, Beykent University Istanbul.

Kara, U. A. (2014). Relationship between Positive Psychological Capital and Individual Performance: The Case of Central Union of Agricultural Credit Cooperatives. Master Thesis, Gazi University, Ankara.

Keser, A. (2005). Relationship Between Job Satisfaction and Life Satisfaction: An Application in the Automotive Sector. Kocaeli University Faculty of Economics and Administrative Sciences, 2, 78-96. 
Kocaçal, Ç. (2016). The Effect of Positive and Negative Thinking on Labor Productivity in Business Employees: Istanbul Province Case. Master Thesis, Beykent University, Istanbul.

Koçak, Ö. F. (2016). The Relationship Between Interpersonal Conflicts and Life Satisfaction: A Research on University Students. The Journal of International Social Research, 9(43),1956-1977.

Kuzulu, E., Kurtuldu, S. ve Vural Özkan, G. (2013). A Study on the Relationship between Life Balance and Life Satisfaction, Sakarya Journal of Economics, 5, 88-127.

Light, H. K., Hertsgaard, D. and Martin, R. E. (1985). Education And Income: Significant Factors İn Life Satisfaction Of Farm Men and Women, Research in Rural Education, 3, 7-12.

Morgenstern, J. (2004). Time Management From Inside Out: The Foolproof System For Taking Control of Your Schedule and Your Life. Second Edition. NY: Holt Paperbacks.

Özdevecioğlu, M.(2003). A Study on Determining the Relationship Between Job Satisfaction and Life Satisfaction, 11th National Management and Organization Congress, Afyon

Polatç1, S. (2011). The Effect of Work Family Propagation and Psychological Well-Being on the Effect of Psychological Capital on Performance. Doctorate Thesis. Erciyes University, Kayseri.

Seligman, M. E. P. and Csikszentmihalyi, M. (2000). Positive Psychology: Anintroduction. American Psychologist, 55(1), 5-14.

Staudinger, U. M., Fleeson, W. and Baltes, P. B. (1999). Predictors Of Subjective Physical Health And Global Well-Being: Similarities And Differences Between The United States And Germany. Journal of Personality and Social Psychology, 76 (2), 305-319.

Şad, B. (2017). The Effect of Burnout Levels on Life Satisfaction of Individuals Working in Hospitality Industry. Master Thesis, Balıkesir University, Balıkesir.

Şekeroğlu, M. Ö. (2013). Investigation of the Relationship of Work-Family and Family-Work Conflicts with Life Satisfaction of Youth and Sports Ministry, General Directorate of Sports General Directorate Workers. Doctorate Thesis, Gazi University, Ankara.

Telef, B. B.(2011). Teachers' Self-efficacy, Job Satisfaction, Life Satisfaction and Investigation of Burnout. Elementary Education Online, 10(1), 91-108,

Tiefenbach, T. and Agekohlbacher, F. (2013). "Happiness and Life Satisfaction in Japan by Gender" German Institute for Japanese Studies (DIJ), 7 (1), 1-21.

Toker, B. (2012). Life Satisfaction Among Academicians: An Empirical Study on The Universities, ProcediaSocial and Behavioral Sciences, 47, 190-195.

Tolan, B. (1980). Depression of Contemporary Society. Ankara: Faculty of Economics and Administrative Sciences Publications.

Uygungil, S. (2017). Investigation of Relationships Between Positive Psychological Capital and Employee Attitudes: An Application in Adana Province. Doctorate Thesis, Atatürk University, Erzurum.

Ünal, S., Karlıdağ, R. ve Yoloğlu, S. (2001). The Relationship Between Burnout and Job Satisfaction Levels with Life Satisfaction in Physicians, Journal of Clinical Psychiatry, 4, 113-118.

Yetim, Ü. (1991). Life Satisfaction in the Organization of Personal Projects. Doctorate Thesis. Ege University, Izmir.

Y1lmaz, E. ve Altınok, V. (2009). Investigation of Levels of Loneliness and Life Satisfaction of School Administrators, Educational Administration in Theory and Practice, S. 59, s. 451-469.

Yiğit, R., Dilmaç, B. ve Deniz .E. M. (2011). Job and Life Satisfaction: Konya Police Department Field Survey, Turkish Journal of Police Studies, 13(3), 1-18. 
Vara, Ş. (1999). Investigation of the Relationships Between Job Satisfaction and General Life Satisfaction in Intensive Care Nurses, Master Thesis, Ege University, Izmir.

Veenhoven, R. (1996). The Study Of Life Satisfaction. In: W. E. Saris, R.Veenhoven, A. C. Scherpenzeel, \& B. Bunting (Eds). A Comparative Study of satisfaction With Life İn Europe Pp. Eotvos University Press, 11-48. 